\title{
"Erwinia nulandii" Is a Subjective Synonym of Erwinia persicinus
}

\author{
DON J. BRENNER, ${ }^{1 *}$ J. RODRIGUES NETO, ${ }^{2}$ ARNOLD G. STEIGERWALT, ${ }^{1}$ AND C. F. ROBBS ${ }^{3}$ \\ Emerging Bacterial and Mycotic Diseases Branch, Division of Bacterial and Mycotic Diseases, National Center for \\ Infectious Diseases, Centers for Disease Control and Prevention, Atlanta, Georgia, ${ }^{1}$ and Instituto Biológico, Seçâo \\ de Bacteriologia Fitopatológica, 13.001-970-Campinas, ${ }^{2}$ and Embrapa-CTAA, 23020 Rio de Janeiro, ${ }^{3}$ Brazil
}

\begin{abstract}
The organism named "Erwinia nulandii" was isolated in 1979 from bean seeds and was described in 1981, but the name was never validated. The results of biochemical tests and membrane protein profile and DNA relatedness studies indicated that this name is synonymous with Erwinia persicinus, a validly published name for a species previously isolated from, but not shown to be pathogenic for, tomatoes, bananas, and cucumbers. Pathogenicity tests revealed that all $E$. persicinus strains, including an " $E$. nulandii" strain, were pathogenic for bean pods and seeds.
\end{abstract}

In 1981, Schuster et al. described a new, pink-pigmented species of bacteria isolated from beans (10) and named the organism "Erwinia nulandii." This name appeared just after the Approved Lists of Bacterial Names (13) was published, and it was never subsequently validated by publication in the International Journal of Systematic Bacteriology. In 1990, Hao et al. (5) described the pink-pigmented species Erwinia persicinus, which was isolated from tomatoes, bananas, and cucumbers. E. persicinus was shown to be distinct from all other validly published erwiniae, including the pink-pigmented species Erwinia rhapontici (9) and Erwinia rubrifaciens (18). "E. nulandii" was not included in the study of Hao et al. because they were not aware of its existence.

This study was undertaken to recharacterize " $E$. nulandii" in order to validate it as a new species. On the basis of the biochemical test, membrane protein profile, and DNA relatedness results which we obtained, it is clear that " $E$. nulandii". is a synonym of $E$. persicinus.

\section{MATERIALS AND METHODS}

Bacterial strains. "E. nulandii" NCPPB 3375 (= Pinky A = IBSBF 793 = ICMP $8932=$ ATCC 49742) was obtained from the National Collection of Plant Pathogenic Bacteria. The type strain of E. persicinus (strain ATCC 35998 [= HK $204=$ CDC $9108-82=\mathrm{AJ} 2716=$ IAM $12843=\mathrm{JCM} 3704]$ ) and strains HK 200, HK 201, and HK 203 were obtained from K. Komagata, Tokyo, Japan. The strains were maintained on glucose-yeast extract-calcium carbonate agar or on nutrient agar. To prepare DNAs, strains were cultivated in nutrient broth at $30^{\circ} \mathrm{C}$ to the late logarithmic or stationary phase. The DNAs of all other organisms used in DNA hybridization studies (Table 1) were prepared previously in the DNA Hybridization Laboratory, Investigation and Surveillance Laboratory Section, Emerging Bacterial and Mycotic Diseases Branch, Centers for Disease Control and Prevention, Atlanta, Ga.

Phenotypic characteristics. Oxidation-fermentation of Dglucose was tested by the method of Hugh and Leifson (6). Tests for production of $\mathrm{H}_{2} \mathrm{~S}$ from cysteine, production of reducing substances from sucrose, production of indole, reduction of nitrate to nitrite, and acid production from carbohydrates (using $\mathrm{C}$ medium) were performed by the methods of Dye (3). Lipolysis of Tween 80 was tested by the method of

\footnotetext{
* Corresponding author. Mailing address: Centers for Disease Control and Prevention, 1-2226, Mailstop D11, Atlanta, Ga 30333.
}

Sierra (11), hydrolysis of esculin was tested by the method of Sneath (14), and oxidase production was tested by the method of Kovacs (7). The presence of protopectinase on potato, carrot, onion, and pepper slices and tyrosinase production were determined by the methods of Lelliott et al. (8). Liquefaction of sodium polypectate was determined by the method of Skerman (12), and utilization of sodium salts of organic acids was determined by the method of Wilkie (17). All other tests were performed as described by Edwards and Ewing (4) or Schuster et al. (10). The oxidase test was read immediately after Kovács reagent was added. All other test preparations were incubated at $28^{\circ} \mathrm{C}$, and the results were recorded after 2 , 5 , or 14 days.

Pathogenicity tests. The pathogenicity of " $E$. nulandii" NCPPB 3375 and the pathogenicity of E. persicinus strains were determined with bean pods (Phaseolus vulgaris cv. Carioca) and the fruits of tomatoes (Lycopersicon esculentum cv. Angela), cucumbers (Cucumis sativus cv. Aodai), and bananas (Musa sp. cv. Nanica). Each pod or fruit was artificially inoculated by placing 1 drop of a bacterial suspension containing approximately $10^{8} \mathrm{CFU} / \mathrm{ml}$ on the surface and then puncturing the surface with a sterile needle. Five samples of each plant were inoculated with each strain. Bananas were detached from the plant and maintained in a laboratory at room temperature. Other plants were maintained for $48 \mathrm{~h}$ in a humid chamber in a greenhouse. Symptoms were recorded 5 days after inoculation.

PAGE of membrane proteins. Polyacrylamide gel electrophoresis (PAGE) of membrane proteins was performed by the method of Thaveechai and Schaad (15), and the gels were stained with silver nitrate by the method of Blum et al. (1). A $12 \%$ sodium dodecyl sulfate (SDS)-polyacrylamide gel was used. The protein patterns were visually compared and analyzed by using a scanning densitometer.

DNA hybridization. The methods used for DNA purification and DNA hybridization on hydroxyapatite have been described by Brenner et al. (2). DNA from " $E$. nulandii" NCPPB 3375 was labeled in vitro with $\left[{ }^{32} \mathrm{P}\right] \mathrm{dCTP}$, which was provided in a nick translation reagent kit (Bethesda Research Laboratories, Inc., Gaithersburg, Md.). An incubation temperature of $60^{\circ} \mathrm{C}$ was used to determine optimal DNA relatedness values, and $75^{\circ} \mathrm{C}$ was used to assess DNA relatedness under stringent conditions. The percentage of relative binding was determined by normalizing the amount of labeled DNA bound to hydroxyapatitie in heterologous reactions to the amount bound in homologous control reactions, in which both the labeled and unlabeled DNAs were from "E. nulandii" NCPPB 3375. The 
TABLE 1. Levels of DNA relatedness between " $E$. nulandii" and other erwiniae

\begin{tabular}{|c|c|c|c|}
\hline \multirow[b]{2}{*}{ Source of unlabeled DNA ${ }^{a}$} & \multicolumn{3}{|c|}{$\begin{array}{l}\text { Labeled DNA from "E. nulandii" } \\
\text { NCPPB } 3375^{b}\end{array}$} \\
\hline & $\begin{array}{c}\text { Relative } \\
\text { binding ratio } \\
\text { at } 60^{\circ} \mathrm{C}\end{array}$ & $\begin{array}{l}\% \text { Diver- } \\
\text { gence }\end{array}$ & $\begin{array}{c}\text { Relative } \\
\text { binding ratio } \\
\text { at } 75^{\circ} \mathrm{C}\end{array}$ \\
\hline "Erwinia nulandil" NCPPB 3375 & 100 & 0.0 & 100 \\
\hline Erwinia persicinus HK 200 & 87 & 0.0 & 89 \\
\hline Erwinia persicinus HK 201 & 83 & 0.0 & 87 \\
\hline Erwinia persicinus ATCC $35998^{\mathrm{T}}$ & 79 & 0.0 & 88 \\
\hline Erwinia persicinus HK 203 & 78 & 0.0 & 81 \\
\hline Erwinia rhapontici ICPB ER $106 \mathrm{C}$ & 66 & 11.0 & 32 \\
\hline Erwinia rhapontici ATCC $29283^{\mathrm{T}}$ & 63 & 10.5 & 33 \\
\hline Erwinia rhapontici ICPB ER 106A & 60 & 11.0 & 29 \\
\hline Erwinia amylovora ICPB EA 178 & 42 & & \\
\hline Erwinia herbicola ATCC $33243^{\mathrm{T}}$ & 40 & & \\
\hline Erwinia milletiae ATCC $33231^{\mathrm{T}}$ & 38 & & \\
\hline Erwinia cypripedii ICPB EC 155 & 36 & & \\
\hline Pantoea ananas ATCC $33244^{\mathrm{T}}$ & 33 & & \\
\hline Erwinia uredovora CDC 9574-82 & 30 & & \\
\hline Pantoea stewartii ATCC $8199^{\mathrm{T}}$ & 29 & & \\
\hline Erwinia psidii $435-84^{\mathrm{T}}$ & 29 & & \\
\hline Erwinia mallotivora $\mathrm{NCPPB} 2851^{\mathrm{T}}$ & 28 & & \\
\hline Erwinia chrysanthemi ATCC $11663^{\mathrm{T}}$ & 26 & & \\
\hline Erwinia carotovora ATCC $15713^{\mathrm{T}}$ & 25 & & \\
\hline Erwinia tracheiphila ATCC $33245^{\mathrm{T}}$ & 24 & & \\
\hline $\begin{array}{l}\text { Erwinia carotovora subsp. } \\
\text { betavasculorum ATCC } 8061\end{array}$ & 21 & & \\
\hline $\begin{array}{l}\text { Erwinia carotovora subsp. wasabiae } \\
\text { ATCC } 43316^{\mathrm{T}}\end{array}$ & 21 & & \\
\hline Pantoea terreus ATCC 31628 & 21 & & \\
\hline Erwinia rubrifaciens ICPB ER 105 & 21 & & \\
\hline Erwinia salicis ATCC $15712^{\mathrm{T}}$ & 20 & & \\
\hline Erwinia quercina ICPB EQ 102 & 19 & & \\
\hline Erwinia cacticida ATCC $49481^{\mathrm{T}}$ & 18 & & \\
\hline Pantoea punctata ATCC 31624 & 18 & & \\
\hline Pantoea citreus ATCC 31623 & 16 & & \\
\hline
\end{tabular}

a NCPPB, National Collection of Plant Pathogenic Bacteria, Harpenden, United Kingdom; ATCC, American Type Culture Collection, Rockville, Md.; ICPB, International Collection of Phytopathogenic Bacteria, University of California, Davis; CDC, Centers for Disease Control and Prevention, Atlanta, Ga.

${ }^{b}$ The relative binding ratios and divergence values are averages from two or more experiments. Before normalization to $100 \%$, the average levels of DNA bound to hydroxyapatite in homologous reactions were $70 \%$ in $60^{\circ} \mathrm{C}$ reactions and $72 \%$ in $75^{\circ} \mathrm{C}$ reactions. The average levels of labeled DNA that bound to hydroxyapatite in control reaction mixtures that did not contain unlabeled DNA were $3 \%$ in $60^{\circ} \mathrm{C}$ reactions and $1 \%$ in $75^{\circ} \mathrm{C}$ reactions. These values were subtracted from all reassociation reaction values before normalization.

percentage of divergence was calculated to the nearest $0.5 \%$ by assuming that each $1{ }^{\circ} \mathrm{C}$ decrease in the thermal stability in a heterologous DNA duplex compared with the thermal stability of the homologous "E. nulandii" DNA duplex was caused by approximately $1 \%$ unpaired nucleotide bases.

\section{RESULTS AND DISCUSSION}

Cells of "E. nulandii" NCPPB 3375 are gram negative, oxidase negative, catalase positive, fermentative, and motile. They produce a pink pigment on glucose-yeast extract-calcium carbonate agar and other media. They give positive reactions in tests for $\mathrm{H}_{2} \mathrm{~S}$ production from cysteine, $\mathrm{H}_{2} \mathrm{~S}$ production from sodium thiosulfate, acetoin production (Voges-Proskauer test), phosphatase activity, reduction of nitrate to nitrite, esculin hydrolysis, growth in the presence of $5 \% \mathrm{NaCl}$, and growth in the presence of $0.0005 \%$ tetrazolium chloride. They give negative reactions in tests for growth at $42^{\circ} \mathrm{C}$, urease activity, gas production from D-glucose, gelatin hydrolysis, starch hydrolysis, production of reducing substances from sucrose, indole production, methyl red, phenylalanine deaminase activity, arginine dihydrolase activity, lysine decarboxylase activity, ornithine decarboxylase activity, lipolysis of Tween 80 , tyrosinase activity, pectinase activity, and production of protopectinase on potato, carrot, onion, and pepper slices.

"E. nulandii" NCPPB 3375 produces acid during fermentation of cellobiose (weakly), D-fucose, fructose, D-galactose, $D$-glucose, $\beta$-methyl-D-glucoside, $m$-inositol, lactose, maltose, D-mannitol, D-mannose, melibiose, L-rhamnose, ribose, D-salicin, D-sorbitol, sucrose, and trehalose, but does not ferment D-arabinose, D-arabitol, L-arabitol, adonitol, dulcitol, erythritol, ethanol, $\alpha$-methyl-D-glucoside, glycerol, inulin, melezitose, palatinose, raffinose, starch, tagatose, D-xylose, or L-xylose.

"E. nulandii" NCPPB 3375 utilizes sodium salts of the organic acids acetate, citrate, fumarate, gluconate, glutarate, hippurate, malonate, mesaconate, nicotinate, oxalate, D-tartrate, L-tartrate, $m$-tartrate, and succinate, but does not utilize benzoate, glycerophosphate, and taurocholate. It utilizes the amino acids DL-arginine, L-arginine, L-glutamine, DL-histidine, L-histidine, L-ornithine, L-proline (weakly), and L-serine, but does not utilize betaine, DL-phenylalanine, L-threonine, $\mathrm{L}$ tryptophan, and L-valine.

The biochemical reactions of " $E$. nulandii" NCPPB 3375 are very similar to the reactions reported previously for the pink-pigmented species E. persicinus (5). The differences observed included acid production from D-fucose in " $E$. nulandii" but not in E. persicinus; acid production from D-melezitose and raffinose in $E$. persicinus but not in " $E$. nulandii"; and acetate utilization in " $E$. nulandii" but not in $E$. persicinus. Like $E$. persicinus, "E. nulandii" is differentiated from the pink-pigmented species $E$. rhapontici by its negative methyl red test, by acetoin production, by a lack of acid production from dulcitol, $\alpha$-methyl-D-glucoside, glycerol, inulin, starch, and D-xylose, and by acid production from $m$-inositol (5). "E. nulandii" is differentiated from the pink-pigmented species $E$. rubrifaciens by its negative methyl red test, by acetoin production, by acid production from cellobiose, $m$-inositol, lactose, and melibiose, and by a lack of acid production from $\alpha$-methyl-D-glucoside and glycerol (5).

E. persicinus ATCC $35998^{\mathrm{T}}$ ( $\mathrm{T}=$ type strain), HK 200 , and HK 201 and " $E$. nulandii" NCPPB 3375 were tested for pathogenicity by inoculating them into plants. None of these strains produced clear-cut rot on cucumbers, tomatoes, or bananas. All strains did produce necrotic symptoms on bean pods and discoloration of bean seeds.

The membrane protein patterns obtained after SDS-PAGE were extremely similar for " $E$. nulandi"" NCPPB 3375 and three strains of $E$. persicinus (Fig. 1). Densitometer tracings of the protein patterns confirmed the similarity of the membrane proteins of these strains (data not shown).

The levels of relatedness between labeled " $E$. nulandii" DNA and unlabeled DNAs from Erwinia strains are shown in Table 1. The levels of relatedness between " $E$. nulandii" and four $E$. persicinus strains ranged from 78 to $87 \%$ (average, $82 \%$ ) with $0 \%$ divergence in $60^{\circ} \mathrm{C}$ reactions and from 81 to $89 \%$ (average, $86 \%$ ) in $75^{\circ} \mathrm{C}$ reactions. The next closest relative of " $E$. nulandii" was $E$. rhapontici; the average level of relatedness at $60^{\circ} \mathrm{C}$ was $63 \%$, with an average level of divergence among related sequences of $11.0 \%$. E. rhapontici is also the closest relative of $E$. persicinis, exhibiting an average level of relatedness at $60^{\circ} \mathrm{C}$ of $66 \%$ and a level of divergence among related sequences of $10.5 \%$ (5).

The recommended genetic definition of a bacterial species is a group of strains that exhibit levels of relatedness of $70 \%$ or 


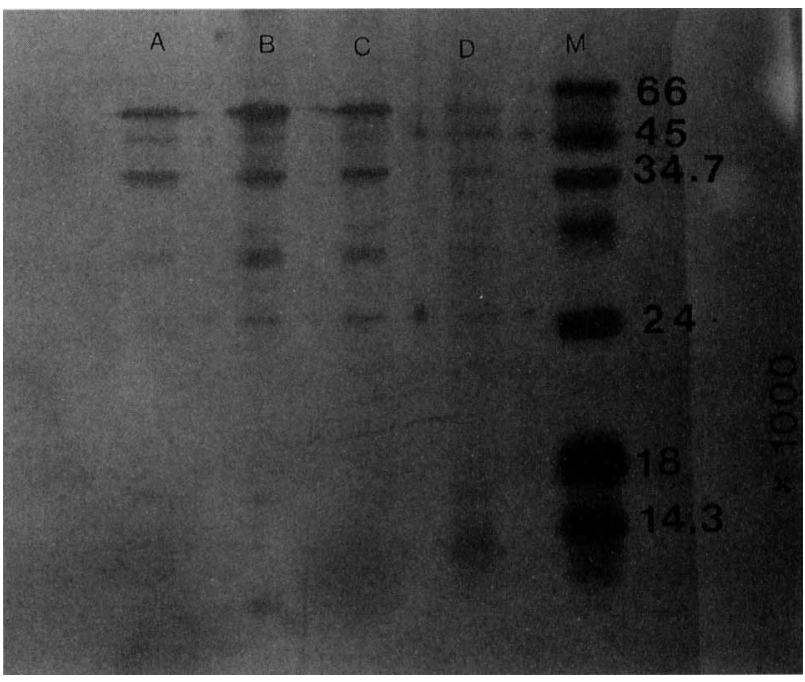

FIG. 1. Membrane protein profiles of E. persicinus and "E. nulandii." Lanes A through C, E. persicinus HK 200, ATCC $35998^{\mathrm{T}}$, and HK 201 , respectively; lane D, " $E$. nulandii" NCPPB 3375; lane M, molecular weight marker Dalton Mark VII

more at an optimal reassociation temperature $\left(60^{\circ} \mathrm{C}\right.$ in this study) and levels of divergence among related DNA sequences of less than $5 \%(16)$. When this definition and the $86 \%$ average level of relatedness at the stringent reassociation temperature were used, there was no doubt that the strains represented by the names " $E$. nulandii" and $E$. persicinus are members of a single species and that these names are synonyms. This conclusion was strengthened by the similar biochemical profiles, protein profiles, and plant pathogenicity characteristics of the strains which we studied.

"E. nulandii" differed from E. persicinus in D-fucose, Dmelezitose, and raffinose fermentation reaction results and in acetate utilization reaction results (5). It is not known whether these differences resulted from differences in the tests used or reflected variability among the strains used in these tests. The fact that the "E. nulandii" and E. persicinus strains were pathogenic for beans provides the first evidence that $E$. persicinus is a plant pathogen. The description of E. persicinus (5) should be emended to reflect this finding.

Resolution of the nomenclatural question of which of the two synonymous names should be used for the single genospecies is simple. Unfortunately, the name " $E$. nulandii" was never validated in the International Journal of Systematic Bacteriology and has no standing in nomenclature. Therefore, despite the fact that " $E$. nulandii" was published 9 years earlier than $E$. persicinus, E. persicinus is the valid name for this species.

\section{REFERENCES}

1. Blum, H., H. Beier, and H. J. Gross. 1987. Improved silver staining of plant proteins, RNA and DNA in polyacrylamide gels. Electrophoresis 8:93-99.

2. Brenner, D. J., A. C. McWhorter, J. K. Leete Knutson, and A. G. Steigerwalt. 1982. Escherichia vulneris: a new species of Enterobacteriaceae associated with human wounds. J. Clin. Microbiol. 15: 1133-1140.

3. Dye, D. W. 1968. A taxonomic study of the genus Erwinia. I. The "amylovora" group. N.Z. J. Sci. 11:590-607.

4. Edwards, P. R., and W. H. Ewing. 1972. Identification of Enterobacteriaceae, 3rd ed. Burgess Publishing Co., Minneapolis.

5. Hao, M. V., D. J. Brenner, A. G. Steigerwalt, Y. Kosako, and K. Komagata. 1990. Erwinia persicinus, a new species isolated from plants. Int. J. Syst. Bacteriol. 40:379-383.

6. Hugh, R., and E. Leifson. 1953. The taxonomic significance of fermentative versus oxidative metabolism of carbohydrates by various gram-negative bacteria. J. Bacteriol. 66:24-26.

7. Kovacs, N. 1956. Identification of Pseudomonas pyocyanea by the oxidase reaction. Nature (London) 178:703.

8. Lelliott, R. A., E. Billing, and A. C. Hayward. 1966. A determinative scheme for the fluorescent plant pathogenic pseudomonads. J. Appl. Bacteriol. 29:470-489.

9. Millard, W. A. 1924. Crown rot of rhubarb. Bull. Univ. Leeds Yorkshire Council Agric. Ed. 134:1-28.

10. Schuster, M. L., A. M. Schuster, and D. J. Nuland. 1981. A new bacterium pathogenic for beans (Phaseolus vulgaris L.). Fitopatol. Bras. 6:345-358.

11. Sierra, G. 1957. A simple method for the detection of lipolytic activity of microorganisms and some observations on the influence of the contact between cells and fatty substrates. Antonie Leeuwenhoek 23:15.

12. Skerman, V. B. D. 1967 . A guide to the identification of the genera of bacteria. The Williams \& Wilkins Co., Baltimore.

13. Skerman, V. B. D., V. McGowan, and P. H. A. Sneath (ed.). 1980 Approved lists of bacterial names. Int. J. Syst. Bacteriol. 30:225420 .

14. Sneath, P. H. A. 1956. Cultural and biochemical characters of the genus Chromobacterium. J. Gen. Microbiol, 15:70.

15. Thaveechai, N., and N. W. Schaad. 1986. Immunochemical characterization of a subspecies-specific antigenic determinant of a membrane protein extract of Xanthomonas campestris pv. campestris. Phytopathology 76:148-153.

16. Wayne, L. G., D. J. Brenner, R. R. Colwell, P. A. D. Grimont, O. Kandler, M. I. Krichevsky, L. H. Moore, W. E. C. Moore, R. G. E. Murray, E. Stackebrandt, M. P. Starr, and H. G. Trüper. 1987. Report of the Ad Hoc Committee on Reconciliation of Approaches to Bacterial Systematics. Int. J. Syst. Bacteriol. 37:463464.

17. Wilkie, J. P. 1973. Basal glume rot of wheat in New Zealand N. Z. J. Agric. Res. 16:155-160.

18. Wilson, E. E., F. M. Zeitoun, and D. L. Fredrickson. 1967. Bacterial phloem canker, a new disease of Persian Walnut trees. Phytopathology 57:618-621. 